\title{
Trends and Potential of the Reindustrialization of the Mining Region
}

\author{
Ludmila Kusurgasheva ${ }^{1}$, Alina Muromtseva ${ }^{1}$, Evgeniya Prokopenko ${ }^{1}$, and Yuliya Yakunina $^{1}$ \\ ${ }^{1}$ Department of Economics, Institute of Economics and Management, T.F. Gorbachev Kuzbass State \\ Technical University, 28 Vesennyaya Street, 650000 Kemerovo, Russia
}

\begin{abstract}
The aim of this work is to develop theoretical foundations for the reindustrialization of the mining region in the context of trends in the spatial development of the Russian economy. The urgency of the problem is caused by the deepening of regional development unevenness, differentiation of regions by structural, resource and institutional parametric characteristics. As a result, the imperative of spatial development of the Russian economy is a consistent modernization of the regional organization of the economy on the basis of the reindustrialization policy. In the macroeconomic context, globalization is associated with overcoming stagnation consequences and entering the trajectory of sustainable innovative growth, stagnation and development mainly in the scenario; in the mesoeconomic context it is associated with accelerated capitalization of the competitive advantages of each region. The exhaustion of the predominantly export-raw material model of economic growth has put Kuzbass - the mining region of Western Siberia, which is heavily dependent on the state of the world market of fuel and energy resources in the most difficult situation. The task of the accelerated transition to the innovative-resource type of development through structural and technological transformation in the context of the General course of neoindustrialization for the region is actualized. This article presents a theoretical justification of the necessity, possibility and feasibility of neoindustrialization of the mining region in the context of globalization.
\end{abstract}

\section{Introduction}

Problem statement. Kemerovo region (Kuzbass) is a region where mining has become a branch of national specialization and one of the system-forming factors of the regional economy. The share of such economic activity "Mining of minerals" in the region's structure and gross value added (GVA) continues to increase, from $21.5 \%$ in 2006 to $29.7 \%$ in 2016. The main natural resource of Kuzbass is coal; the region is one of the largest in Russia in terms of its reserves and production volumes. Since the beginning of 2000-ies the coal production in the Kuzbass has been growing steadily, doubling over the last 15 years.

At the end of 2017, the Kemerovo region reached an absolute historical maximum in this indicator - 241.5 million tons of coal were mined $(59 \%$ of the all-Russian volume of coal and $80 \%$ of coking coal volumes). The main driver of growth is an increase in exports (gas makes effective competition for coal in the domestic market). Coal exports in 2017 increased by $13 \%$, reaching 140.7 million tons, while the geography of supplies expanded. 
Coal is supplied to 61 countries (in 2016 - 55 countries). However, the active development of coal deposits in the Kemerovo region has both environmental and socio-economic limits. It can be rightfully argued that the prospects for balanced and sustainable economic growth of Kuzbass look problematic within the current trends of spatial development of the world and Russian economies.

\section{Materials and Methods}

The main problem is that these trends strengthen the region's raw material specialization and determine its place as a periphery in the structure of the Russian economic space. This fact emphasizes the need for neoindustrial rotation in the development of the Kemerovo region as a typical resource-producing region. By the end of 2018, it is planned to develop a strategy for the spatial development of the Russian Federation, within the framework of which the principles and mechanisms for the implementation of the state regional policy should be revised with the transition from non - system, inefficient practice of "manual" management to scientifically based policy, taking into account new economic and geopolitical realities. On the basis of the analysis of objective factors and barriers of spatial development of the Russian economy in modern conditions the necessity, possibility and expediency of neoindustrialization of the resource-extracting region will be proved in this work.

Interrelationship of the work with previously published works. The whole amount of special literature, which is significant for the research topic, can be divided into two blocks. The first block is represented by works on spatial Economics, which has been developing quite successfully over the past half-century. Its main idea can be expressed in words: "Space matters" [1]. The most important conclusion of spatial research is the provision that the socio-economic development of certain regions can not be uniform: the accelerated development of one region causes slower growth in other regions (on the periphery), thus causing increased differentiation of regions in terms of welfare [2]. Numerous authors based their understanding of differentiation of regions on this situation. Thus, G. M. Myrdal formulated the principle of "cumulative (circular) causality", according to which regional imbalances have a cumulative character: developed countries are developing more rapidly, and backward - are increasingly lagging behind in development [3]. The theory of feedback" by A. Hirschman, which is based on the concept of unbalanced regional development due to unbalanced growth caused by a shortage of resources and other factors of production in a certain territory [4], along with the ideas of Myrdal, was an incentive for further research in this area. The theory of cumulative growth also includes the concept of poles of growth by F. Perroux [5]. The essence of this concept lies in the statement that accelerated economic growth occurs in different parts of the space with different frequencies and at different times. F. Perroux points to industrial complexes and industries that can be a source of economic growth, calling them poles of growth. An important point of the F. Perroux concept is the provision on the active role of the state in creating poles of growth, which, possessing a powerful growth potential and a high ability to innovate, can reduce or inhibit the growth of inequality in regional development. A well - known model of spatial development "centre-periphery", the author of which is J. Friedmann [6] expands understanding of laws of spatial development. In this model there is a developed center and underdeveloped periphery. Industrialization processes have led to the formation of large urban centres in which industrial production and the population are concentrated and which have therefore gained a well - known advantage in terms of the agglomeration effect (increased economic efficiency due to the geographical concentration of economic activity). The agglomeration effect, ensuring the dominance of the center, is achieved by tightening the resources (human, financial, natural) from the periphery, so that the centre is able to 
innovative development, and the periphery becomes the environment of their distribution ("diffusion of obsolete innovations").

A new impetus to the development of spatial Economics was given by research in the framework of the "new economic geography" (NEG), the final design of which is associated with the release in 1999 of the book by M. Fudzita, P. Krugman and E. Venables [7]. The main idea of NEG is the provision that increasing economies of scale are a determining factor in the occurrence of agglomerations, as well as changes in a number of their characteristics [8]. P. Krugman was one of the first to apply modern neoclassical models to the analysis of the uneven distribution of economic activity in space [9]. Krugman distinguished competitive advantages into factors of the "first nature" - objective advantages independent of people (wealth of natural resources, favorable geographical position) and factors of the "second nature" - advantages associated with the activities of economic actors (institutions, the agglomeration effect, human capital, the infrastructure). At the same time, factors of the second nature, which to a greater extent determine regional convergence or divergence, acquire dominant importance at the present stage.

Thus, a review of the spatial concepts leads to the conclusion that economic space is not homogeneous and most of the operational design is the model "core - periphery", which allows to conduct an empirical study of the factors of development in different potential regions.

The second block of the literature includes studies of reindustrialization as a global trend and imperatives of strategic development of mining regions. It is known that one of the first works in this area was article by J. Miller with co-authors, in which reindustrialization was defined as combining the efforts of the state, business and the education system to develop and implement a coordinated industrial policy aimed at restoring the industrial potential of the country [10]. A more modern understanding of reindustrialization focuses on the priority development of the real sector (as compared to the services sector), with an emphasis on innovation and the recognition of the need for government intervention [11]. For mining regions, an important conclusion of studies of reindustrialization is the recognition of its specific content, depending on the industrial policy of the state. In particular, until recently it was widely believed that countries rich in natural resources with a focus on exports, do not have long term incentives for sustainable economic growth and human development because the abundance of resources restricts investment in other sectors of the economy, leads to de-industrialization due to the "Dutch disease", increases inequality, causing environmental destruction, stimulates corruption and rent-seeking behavior.

The negative correlation between resource abundance and economic growth, established by J. E. Sachs and Warner [12], was so called a resource curse. At the same time, there are theoretical and empirical studies that prove that the impact of resources on development depends to a large extent on the institutional environment. While institutions provide good protection of property rights and create a favorable investment climate, countries rich in natural resources not only demonstrate accelerated economic growth, but also provide positive dynamics in the human development index [13-14]. It can be concluded that the main direction of reindustrialization is the institutional policy of the state aimed at stimulating the use of objective competitive advantages of the regions.

The results of our review of the theories of spatial development and reindustrialization substantiate the thesis of the need for re-industrialization of the resource sector of the Kuzbass economy as a strategic direction for the development of the regional economy. This approach makes it possible to assess the real impact that the region can achieve by non-industrialization of the sector for the integrated socio-economic development of the territory. 


\section{Results and Discussion}

1. Analysis of the potential for reindustrialization of the Russian economy showed that the objective factors influencing the possibility of its implementation are: globalization, causing (in the absence of adequate challenges of the new era of the strategy of innovative development) Russia's lagging behind developed countries; neoliberal economic policy of the state, which caused the destruction, degradation and stagnation of the economic potential of the region; strengthening of the geopolitical vector and sanctions regime against the Russian economy; stagnation of the Russian economy in the conditions of completion of the world economy development cycle and transition to a new technological order; high natural-resource potential and strengthening of regional imbalances and peripherization of the all-Russian space. The Kemerovo region is characterized by: progressive deindustrialization of the region, insufficiently high economic potential and high investment risks caused by the dependence of the region on the state and trends of the world economy; significant migration outflow to the Western and southern regions of the country and a significant deterioration in the conditions necessary for the reproduction of human potential; poor quality of institutions. The results of the analysis show that in the development of the Kemerovo region, in fact, an inertial scenario of long-term development is being implemented, which follows from the established trends and implies economic growth by strengthening the region's raw material specialization (increasing production and primary processing of raw materials). It can be argued that the raw material specialization of the Kemerovo region becomes a barrier to sustainable and balanced economic growth.

To overcome this trend, huge investments are needed, and private Russian capital is focused only on short - term profits and, most importantly, does not demand innovation. The increase in prices in the world commodity markets in the early 2000 s allowed to intensify the investment process in the coal industry of Kuzbass. However, firstly, the investments were insufficient for technological and organizational modernization of coal enterprises, which should ensure the growth of productivity and labor safety. Secondly, investments in the coal industry have not and could not have been drivers of growth in other sectors, since the necessary equipment was mainly imported from abroad. In general, the level of depreciation of fixed assets in the industry is approaching a critical level in Kuzbass; if today any funding for the renewal of fixed assets is completely stopped, the average "stock" of depreciation (about 56\%) will allow the manufacturing industry to exist no more than 10 years. At the same time, the most alarming situation is observed in the chemical (53\%) and light industry (49\%), as well as metallurgy (43\%). In addition, the critical value of depreciation of infrastructure: the deterioration of electrical networks $77 \%$, boiler $-67 \%$, water $-60 \%$ of heat networks $-53 \%$.

2. Reindustrialization in modern conditions acts as an adaptive-restorative reaction of the Russian economy (to the previous and current crisis in the industrial sector, transformation in the global economic situation, changes in the system "center-periphery") and is associated with the formation in it of modern industries and segments, with its technological and institutional modernization. The regional measure of reindustrialization in respect of the Kemerovo region is to stimulate the state innovation and investment activity of coal enterprises; modernization of the education system in the direction of growth of training with higher professional and secondary education, as well as the creation of a system of continuing education; strengthening of vertical integration in the economy achieved in the framework of the formed innovation cluster of the Kemerovo region "Complex processing of coal and industrial waste". The positive experience of the Ruhr region of Germany [15] testifies to the need to intensify work in the field of import substitution and export promotion of high-tech products, especially within the framework of the emerging clusters. Important elements of potential re-industrialization is also the 
infrastructure of innovative activities, which relate primarily to development institutions and public-private partnership in various fields and spheres of activity, which received a certain development in the region.

3. The problem of the situation is not only that in these conditions the main subject of reindustrialization can and should be the state, which will need not only to invest budget money and radically change the General ideology and specific methods of economic policy, but also that modernization through reindustrialization calls into question the development of the social sphere, which is currently experiencing a crisis. And for the Kemerovo region, this problem is even more acute, because one of its specific features is the low quality of human potential (low level of education, narrow specialization of professional skills, degradation of health, low mobility of the population, low level of adaptability to changes, unprepared for innovation, etc.).

As a result, reindustrialization acquires a pronounced investment aspect. Since the main problem, the solution of which is directed to the state regional policy, is overcoming excessive socio-economic inequality of the subjects of the Russian Federation, the main principle should be investment inequality in favor of the peripheral territories. There are domestic developments of a technique of construction of the differentiated investment modes on the basis of definition of the investment mode in each concrete region.

\section{Conclusion}

Reindustrialization as a global trend and imperative for the development of resourceproducing regions is formed in the context of increasing global and regional inequality. Under the circumstances, the question of reindustrialization in the Kemerovo region is quite problematic. The trend of socio-economic development of Kuzbass is its increasing specialization in mining, which does not form the demand for innovation and highly skilled workforce and thereby oppressive impact on high-tech industries. On the other hand, the development of territories is heavily influenced by subjective factors, which include regional policy, which is a part of the macroeconomic policy of the state. It is precisely from the actions of the state that the implementation of the reindustrialization policy in the Russian regions, in which it is necessary to purposefully create conditions for the development of the innovation economy potential, largely depends today. The Kemerovo region has significant industrial potential in the coal and chemical industries, in non-ferrous and ferrous metallurgy. Sufficiently high potential of machine-building and construction complexes, largely destroyed during the years of reforms, can be restored under the condition of adequate industrial policy. The educational potential of the Kemerovo region needs further development and modernization. The region has also created the necessary elements for the development of innovative economy innovation infrastructure.

\section{References}

1. C. J. Dawkins, Journal of Planning Literature, 2, 131 (2003)

2. G. Lux, Journal of Economics \& Management, 19, 16 (2015)

3. G. M. Myrdal, Economic Theory and Under-Developed Regions (Duckworth, London, 1957)

4. A. O. Hirshman, The Strategy of Economic Development, (Yale University Press, New Haven, 1958)

5. F. Perroux, Materiaux pour une analyse de la croissance économique (I.S.E.A, Paris, 1955) 
6. J. Friedmann, Regional Development Policy: A Case Study of Venezuela (MIT Press, Boston, 1966)

7. F. Masahisa, P. Krugman and A. J. Venables, The spatial economy: Cities, regions, and international trade (MIT Press, Cambridge, 1999)

8. R. Arnott, N. Wrigley, Journal of Economic Geography, 1, 1 (2001)

9. P. Krugman, Geography and Trade (MIT Press, Cambridge, 1991)

10. J. Miller, T. Walton, W. Kovacic, J.Rabkin, Yale Journal on Regulation, 1, 1 (1984)

11. P. Prisecaru, Knowledge Horizons - Economics, 2, 21 (2014)

12. J. D. Sachs, A. Warner, Natural Resource Abundance and Economic Growth (NBER Working Papers 5398, Cambridge, 1995)

13. H. Mehlum, K. Moene, R. Torvik, Economic Journal, 508, 1 (2006)

14. B. McMahon, S. Moreira. The Contribution of the Mining Sector to Socioeconomic and Human Development (World Bank, Washington, 2014)

15. D. K. Carter, Remaking Post-Industrial Cities: Lessons from North America and Europe (I.S.E.A, Paris, 2016) 